\title{
Gondolatok az új amerikai hipertóniaajánlásról
}

\author{
Nagy Viktor
}

Semmelweis Egyetem, Általános Orvostudományi Kar, II. sz. Belgyógyászati Klinika, Budapest

Levelezési cím:

Dr. Nagy Viktor, Semmelweis Egyetem, Általános Orvostudományi Kar, II Belgyógyászati Klinika

1088 Budapest, Szentkirályi utca 46. E-mail: nagy.viktor@med.semmelweis-univ.hu

\begin{abstract}
A 2017-ben kiadott amerikai hipertóniaajánlás megváltoztatta a magasvérnyomás-betegség meghatározását és kezelését. Az új határérték 130/80 Hgmm. A hipertónia első fokozata 140/90 Hgmm-ig terjed és elsősorban nem gyógyszeres kezelést igényel, de a kardiovaszkuláris kockázat nagyságától függően ez gyógyszeres kezeléssel is kiegészíthető. 140/90 Hgmm felett nem gyógyszeres és gyógyszeres kezelés egyaránt szükséges, utóbbi lehetőleg fix dózisú kombinációból álljon. Az ajánlás a kardiovaszkuláris események erőteljes csökkentésének jegyében készült.
\end{abstract}

Kulcsszavak: prevenció, hipertónia meghatározása, célvérnyomás, kezelés

\section{Troughts about the new American Hypertension Guideline}

The American hypertension recommendation issued in 2017 changed the definition and treatment of hypertension. The new limit is $130 / 80 \mathrm{mmHg}$. The first stage of hypertension ranges to $140 / 90 \mathrm{mmHg}$ and requires primarily non-drug therapy, but depending on the magnitude of cardiovascular risk, it can be supplemented with drug treatment. Above $140 / 90 \mathrm{mmHg}$, non-drug and drug treatment is required, the latter being preferably a fixed-dose combination. The recommendation was made in the spirit of a strong reduction of cardiovascular events.

Keywords: prevention, defining of hypertension, target value of blood pressure, treatment

\section{Bevezetés}

2017. november 12-én még a felnőtt ( $\geq 20$ éves életkor) amerikai állampolgárok 32\%-a volt hipertóniás, november 13-án este már 46\% (1). Nem a magas vérnyomás járványos terjedéséről van szó, „csupán” arról, hogy tizenharmadikán ismertették az American Heart Association (AHA) kongresszusán Anaheimben az új amerikai hipertóniaajánlást. Ebben pedig számos új elvet hirdettek ki, nyugdíjazták pl. a 140/90 Hgmm-es határértéket, az újat pedig 130/80 Hgmm-ben határozták meg (2). Az ajánlásból szubjektív megközelítéssel néhány nagyon fontos és érdekes megállapítást ismertetek (1. táblázat).

\section{Mi lett a normális vérnyomás és a magas vérnyomás határa?}

Az amerikai ajánlás szerint a vérnyomást egészen új értéktartományokkal kell osztályozni és megváltoz- tatták a magas vérnyomás határértékét is. Normálisnak tekintik továbbra is, ha a vérnyomás $<120 / 80$ Hgmm, ám hipertóniáról beszélnek $\geq 130 / 80 \mathrm{Hgmm}$ esetén. Az emelkedett vérnyomásúak kerültek e két kategória határai közé. Az új besorolás jelentős mértékben megnövelte az amerikai hipertóniások számát, megnőtt a gondozási feladat és több beteget kell majd kezelni. A szerzők ugyanakkor azt hangoztatták, hogy az 1. fokozatú hipertóniásoknak csak ak-

\begin{tabular}{|c|c|c|c|}
\hline Kategória & $\begin{array}{l}\text { Szisztolés } \\
\text { vérnyomás (SBP) }\end{array}$ & & $\begin{array}{l}\text { Diasztolés } \\
\text { vérnyomás (DBP) }\end{array}$ \\
\hline Normális & $<120 \mathrm{Hgmm}$ & és & $<80 \mathrm{Hgmm}$ \\
\hline Emelkedett & $120-129$ Hgmm & és & $<80 \mathrm{Hgmm}$ \\
\hline \multicolumn{4}{|l|}{ Hipertónia } \\
\hline 1. fokozat & 130-139 Hgmm & vagy & 80-89 Hgmm \\
\hline 2. fokozat & $\geq 140 \mathrm{Hgmm}$ & vagy & $\geq 90 \mathrm{Hgmm}$ \\
\hline
\end{tabular}

1. TÁBLÁZAT. A rendelői vérnyomás osztályozása felnőttekben az új amerikai ajánlás szerint (2) 
kor kell gyógyszert is kapniuk, ha nagy a kardiovaszkuláris (CV) kockázatuk, vagy már kialakult bennük valamilyen ateroszklerotikus kardiovaszkuláris betegség (ASCVD) (2).

\section{Rövid történelemóra a hipertónia határértékéröl}

A rendelöi vérnyomás nagysága folyamatos és minden más tényezőtől független kapcsolatban áll bármely ASCVD fellépésének kockázatával és a végstádiumú vesebaj kialakulásával. Ez az összefüggés kb. 110-115/70-75 Hgmm-nél kezdődik és a halálos koszorúér-betegség, valamint a szélütés kockázata 20/10 Hgmm-enként duplázódik (3). A szisztolés vérnyomás (SBP) pontosabban jelzi elöre a kockázatot, mint a diasztolés vérnyomás (DBP) (4). Hol van tehát a magasvérnyomás-betegség határa, meddig kell tekinteni normálisnak a vérnyomást és mekkora érték a kóros? Erre teljes biztonsággal még mindig nem lehet pontos választ adni. Az elmúlt 100 év során volt, aki hipertóniásnak azt tekintette, akinek az SBP-je meghaladta a 100 + életkor értéket, vagy a 160/95 Hgmm-t, vagy az 1990-es évek óta a 140/90 Hgmm-t. Némely ASCVD fennállásakor, vagy éppen az életkor függvényében ez az érték felfelé-lefelé minimálisan módosult. A hipertónia $\geq 140 / 90 \mathrm{Hgmm}$-rel jellemzett definíciója végül is nem azon alapul, hogy a vérnyomásgörbén egy mutatóujj hova bök, hanem azon, hogy számos véletlen besorolásos, kontrollcsoportos vizsgálat (RCT) során ezen érték alá csökkentve a betegek vérnyomását, csökkentek a CV-események $(5,6)$.

\section{Kardiovaszkuláris kockázat az alacsony vérnyomástartományokban}

Az ASCVD kockázata azonban nemcsak 140/90 Hgmm felett növekszik, hanem az alatt is. Ezért több RCT-t szerveztek az elmúlt évtizedben (ACCORD, SPRINT, HOPE-3), hogy tisztázzák a hagyományos vérnyomáscsökkentéshez képest, az erőteljes vérnyomáscsökkentés CV-eseményekre kifejtett esetlegesen kedvezőbb hatását (7-9). A három tanulmányba beválasztott betegek kockázatukat illetően eltértek egymástól, de a primer végpont minden esetben a halálos és nem halálos CV-események különféle kombinációja volt. Az intenzív vérnyomáscsökkentő kezelés mellett csak a SPRINT-tanulmányban figyelték meg a primer végpont szignifikáns csökkenését, elsősorban a különféle mortalitás típusok csökkentek, ezért idő előtt fel is függesztették a vizsgálatot (8). A másik két tanulmányban a primer végpont kockázatának csökkenése (7-12\%) nem volt szignifikáns mértékủ $(7,9)$. A kombinációs végpontok összetevői közül az ACCORD-ban a különféle szélütés típusok gyakorisá- ga szignifikáns mértékben csökkent, ám éppen ezt a csökkenést a másik két tanulmányban nem észlelték. A SPRINT-ben a mortalitáson kívül a szívelégtelenség kockázata is csökkent. Mindhárom vizsgálatban az intenzíven kezelt betegek között szignifikáns mértékben megnőtt a kezeléshez kapcsolható mellékhatások gyakorisága (7-9).

A három tanulmány kiindulási vérnyomása elég alacsony volt, csak a SPRINT esetében érte el az SBP a $140 \mathrm{Hgmm}$-t. Az alacsonyabb vérnyomástartományban azonban nem úgy alakul a CV-kockázat, mint a magasban. Az ONTARGET-tanulmányban, ha az SBP $>140$ Hgmm volt, akkor bármely kimenetel előfordulásának gyakorisága nagyobb volt, mint a 120-140 Hgmm közötti tartományban. A $70 \mathrm{Hgmm}$ alatti DBP pedig az összes magasabb DBP-értékkel összehasonlítva a legnagyobb kimeneteli kockázattal járt együtt. $\mathrm{Ha}$ a végeredményt nézzük, amennyiben az elért SBP 120 Hgmm-nél kisebb lett, akkor a szívinfarktus és a szélütés kivételével megnőtt a CV-események kockázata. Ezek az adatok arra hívják fel a figyelmet, hogy a túlzottan alacsony vérnyomás valószínűleg nem optimális a remodellálódott érrendszerü nagy CV-kockázatú betegek számára (10).

A túlzottan erőteljes vérnyomáscsökkentő kezelés tehát lehet, hogy nem hasznos, a másik oldalról szemlélve a dolgokat, azonban a metaanalízisek azt sugallják, hogy annak idején a JNC 7 ajánlásban elkülönített prehipertónia (120-139/80-89 Hgmm) osztályba tartozó egyének CV-kockázata (mortalitás és morbiditás is) nagyobb, mint a normális vérnyomásúaké. Kiderült az is, hogy a prehipertónia felső tartományában a CV-mortalitás kockázata szignifikáns mértékben megnő, míg az alsó tartományában nem (11).

$A z$ ajánlás szakértői szerint az új vezérfonalnak pragmatikusan tükröznie kell a vérnyomás és a CV-kockázat szoros kapcsolatát, ezért módosították a vérnyomás osztályozását. Véleményük szerint az alacsonyabb határérték haszna a megelőzésben, a figyelemfelhívásban és a kezelés bevezetésének pontos és szakszerủ időzítésében mutatkozik majd meg. $\mathrm{Az}$ alacsonyabb vérnyomástartományban természetesen nem ismeretlen a vérnyomáscsökkentők alkalmazása. Szívelégtelenségben és szívinfarktus után a szekunder prevenció érdekében a renin-angiotenzinaldoszteron-rendszer (RAAS) gátlószerei közül az angiotenzin konvertáló enzimgátlókat (ACE-gátló), vagy ACE-gátló intolerancia esetén az angiotenzinreceptor-blokkolókat (ARB), továbbá a bétareceptor-blokkolókat (BBI) kontraindikáció hiányában rutinszerủen kell adni, miközben a betegek gyakran normo-hipotóniásak. Ezekben a betegekben ún. „szubterápiás” adagokkal kell bevezetni a kezelést és bár a nagy tanulmányokban adott, viszonylag nagy adagokat kellene elérni, de a mellékhatások (föleg a várhatóan súlyos hipotónia és vesefunkció-zavar) miatt ez sokszor lehetetlen. 


\section{A vêrnyomáscsőkkentő kezelés szabályai}

Az ajánlás megszűntette azt a klasszikus gyakorlatot, hogy ha magas a vérnyomás, akkor kell szedni valamilyen elsővonalbeli gyógyszert, és ha sikerült elérni a célvérnyomást, akkor minden rendben van.

Amerikában minden olyan esetben, ha ASCVD kialakulása várható, meg kell határozni a kialakulás 10 éves kockázatát az internetröl szabadon letölthető, már pár éve használt AHA/ACC kockázatbecslő program segítségével (http://tools.acc.org/ASCVD-Risk-Estimator/). Mivel a hipertónia az ASCVD vezető rizikófaktora, elöször természetesen el kell végezni a kockázatfelmérést, majd ezután a vérnyomás magasságától függően életmód-változtatással, és/vagy gyógyszer adásával kell végezni a kezelést (1. és 2. ábra).

A szakértők véleménye szerint az USA felnőtt lakosságának kb. $80 \%$-át tartósan érinti a hipertónia több súlyos kockázati tényezője, föleg az elhízás, a túlzott sóés alkoholfogyasztás, valamint az inaktív életmód. A kezelés első lépése ezért minden esetben az életmód megváltoztatása. Ennek I./A evidenciaszintű elemei a következők: testsúlycsökkentés, DASH-diéta, sóbevitel csökkentése, káliumbevitel növelése (új elem, lehetöleg az étrend módositásával, ha az vesebetegség, vagy hiperkalemizáló gyógyszerek adása miatt nem kontraindikált), fizikai aktivitás növelése, alkoholbevitel csökkentése.

A gyógyszeres kezelést illetően új szabályokat javasoltak:

- ha a vérnyomás $\geq 130 / 80$ Hgmm, a nem gyógyszeres kezelés alkalmazása szükséges és akkor kell azt gyógyszerrel kiegészíteni, ha az ASCVD már fennáll (szekunder prevenció), vagy a 10 évre elöre vetített ASCVD-kockázat $>10 \%$ (primer prevenció), - ha a vérnyomás $\geq 140 / 90$ Hgmm, akkor nem gyógyszeres és gyógyszeres kezelés egyaránt szükséges

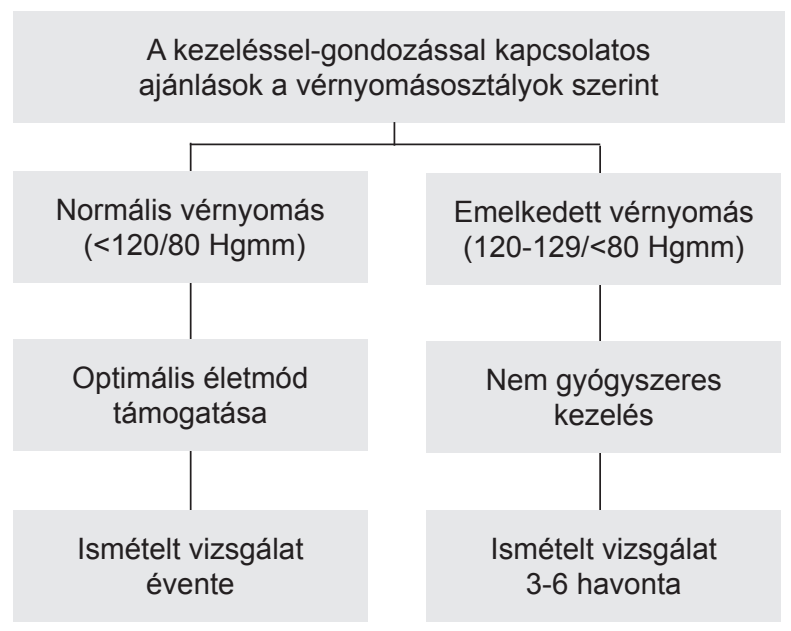

1. ÁBRA. Nem hipertóniás egyének gondozása a vérnyomásosztályok szerint (2) (akkor is, ha nincs szövődmény, vagy célszervkársodás, és a 10 évre előre vetített ASCVD-kockázat $<10 \%$ ), mert a cél a CV-betegségek primer prevenciója.

Az ajánlás szerzői szerint a vérnyomásosztályok módosításával egy olyan preventív szemléletű ajánlást készítettek, amelynek alapján bár jelentős mértékben megnő az amerikai hipertóniások száma, de a gyógyszerrel kezeltek aránya ennél várhatóan jóval kisebb mértékben növekszik majd.

I. fokozatú hipertóniában, ha csak nem gyógyszeres kezelés szükséges, akkor 3-6 havonta kell ellenőrizni a betegek vérnyomását, ha azonban gyógyszert is kell adni, akkor havi vérnyomás-ellenőrzést javasolnak. II. fokozatú hipertóniában a beteg kivizsgálását egy hónapon belül el kell végezni, a kezelést ezzel párhuzamosan el kell indítani, a vérnyomást pedig havonta kell ellenőrizni. Azokra a betegekre, akiknek a vérnyomása nagyon magas, $\geq 180$ / és, vagy $\geq 110$ Hgmm más szabályok vonatkoznak, a kezelést és vérnyomás-ellenőrzést speciális módon kell végezni.

Az európai ajánlással ellentétben az elsőnek választható gyógyszerosztályokból hiányoznak a BBI-k. A vérnyomáscsökkentő gyógyszercsoportok közül a diuretikumok, ACE-gátlók, ARB-k és kalciumcsatorna-blokkolók (CaA) azért a kezelés elsődleges szerei, mert nagyszámú bizonyítékkal rendelkeznek a CV-ese-

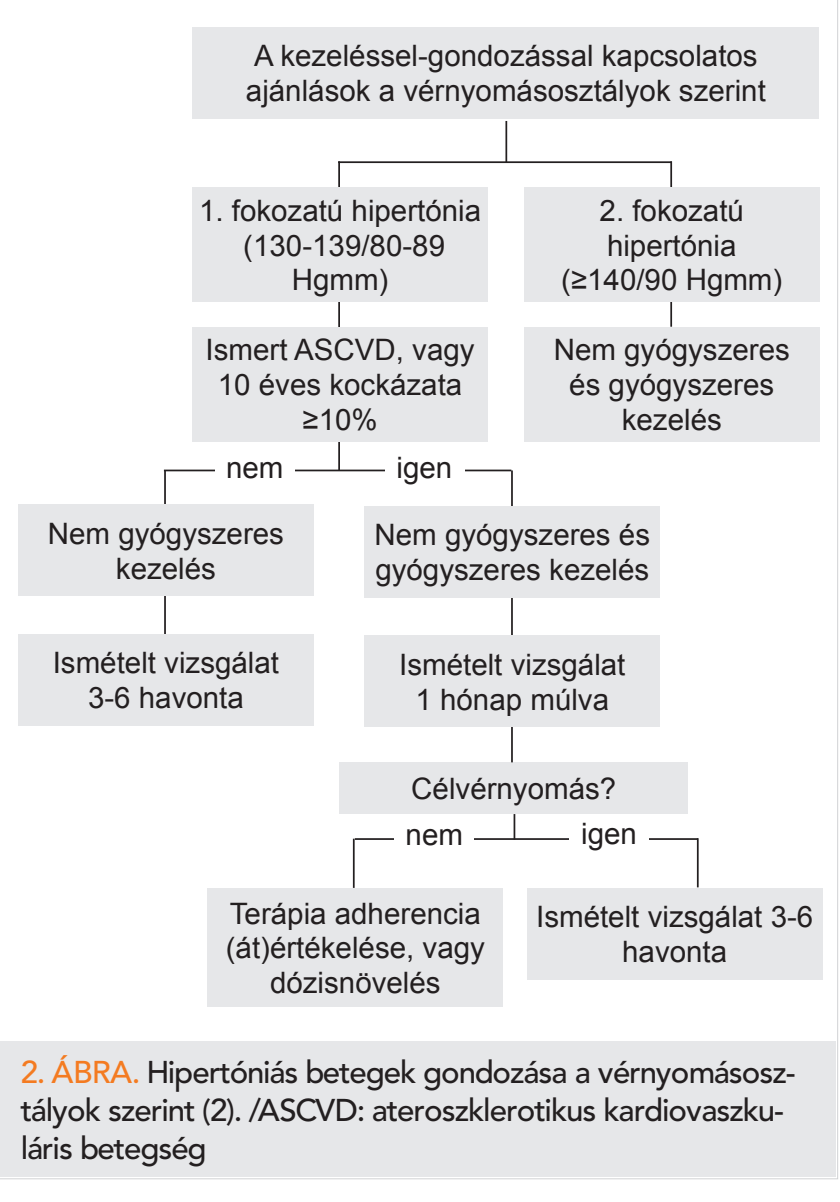


mények csökkentését illetően. A BBI-k esetében viszont az a legnagyobb probléma, hogy ha nem áll fenn speciális kardiológiai indikáció (pl. szívelégtelenség, vagy szívinfarktus utáni állapot), akkor nem bizonyított a CV preventív hatásuk, ezért nem kerültek be az első vonal szerei közé. A második vonal szerei alkalmasak a vérnyomás csökkentésére, bár a tolerálhatóságuk és biztonságosságuk problematikus lehet, és szintén hiányoznak a bizonyítékok a kardiovaszkuláris prevenciót illetően.

A gyógyszerválasztás elveinek legnagyobb módosítása a fix dózisú kombinációk (FDC) előtérbe való helyezése. A szakértők az ismert és évtizedek óta követett elveket (elsőnek választandó gyógyszerek, betegspecifikus tényezők, komorbiditás, párhuzamos gyógyszerelés, gyógyszer-interakciók, egyéni és társadalmi költségek) hangoztatva, a gyógyszerhúség megtartására és a nagyobb hatékonyság-kevesebb mellékhatás elve alapján a 2-3 hatóanyagot fix kombinációban tartalmazó kezelésre irányították a figyelmet. A betegek elsősorban az egy szem tabletta bevételét fogadják el, a kezelésre azonban általában azok adják a legkedvezőbb vérnyomásválaszt, akik több támadásponton ható készítményt kapnak. Ezért ha a hipertónia 2. fokozatú ( $\geq 140 / 90$ Hgmm!!!), akkor már első lépésként is a két hatóanyagból álló, megfelelő dózisú FDC alkalmazása javasolható. Természetesen az ajánlás tartalmazza azt a megjegyzést, hogy a kétkomponensü FDC különösen akkor jön szóba, ha a vérnyomás a célértéket 20/10 Hgmm-rel meghaladja.

A kombinációs kezeléssel elérhető az, hogy a két, vagy három összetevő a vérnyomást optimális mértékben csökkenti, a kevesebb mellékhatás pedig vagy a megszokottnál kisebb adagra, vagy pedig a kedvező interakciókra vezethető vissza. A kettő, vagy három öszszetevőjü FDC-kezelés legfőbb előnyei a következők:

1. megnöveli a terápiahüséget,

2. leegyszerüsíti a kezelést,

3. általában felgyorsítja a célvérnyomás elérését,

4. megnöveli a kezelésre reagálók arányát (dózistól függően a betegek 75-95\%-ában érhető el a célvérnyomás),

5. általában csökkenti a monoterápia provokálta mellékhatásokat,

6. a vérnyomást és a kardiovaszkuláris kockázatot is több támadásponton csökkenti,

7. az összetevők flexibilis összetételű dózisait tartalmazzák.

Pontosan meghatározták a tiltott kombinációkat, hiszen a mindennapi gyakorlatban számos teljesen értelmetlen kombinációval lehet találkozni, pl. kétféle ACE-gátló adása számos esetben előfordul. Tiltott kombinációnak számít az azonos gyógyszerosztályon belüli kombináció (pl. 2 béta-blokkoló, ACE-gátló, nondihidropiridin kalciumantagonista stb.), azonos hatású gyógyszerosztályok kombinációja (ACE-gátló, $A R B$, direkt renin gátló - DRA), ugyanakkor javasolható a thiazidok és káliummegtakarító diuretikumok sőt alkalmanként a kacsdiuretikumok; valamint a dihidropiridin és nondihidropiridin CaA-k kombinációja is.

A tanulmányok alapján, ha az ASCVD már fennáll, vagy kialakulásának 10 évre előre vetített kockázata $>10 \%$, akkor a célvérnyomás <130/80 Hgmm, ha azonban ASCVD nincs és a kockázat is az említettnél kisebb, a <130/80 Hgmm-es célvérnyomás elérésének evidenciaszintje alacsony, csupán „célszerü”-nek tartható.

\section{Következtetések}

\section{Bizalom és bizonyíték}

Egy rövid összefoglalóban nem lehet teljes mértékben ismertetni egy csaknem 200 oldalas módszertani ajánlást, amelyhez terjedelmes statisztikai melléklet csatlakozik. A komorbiditásokkal foglalkozó fejezetek érdekesek, de sok szempontból megegyeznek az európai, magyar és egyéb angolszász nyelvterületen már megjelentekkel. Mindenesetre az új amerikai hipertóniaajánlás szerzői megváltoztatták a megszokott célvérnyomást, vérnyomás-osztályokat és a kezelés alapjait. Ezt azért tették, mert számításaik szerint így a CV-prevenció hatékonyabb lesz. Reméljük, hogy ezt jól tudják a betegek is és nem egy elvetélt statisztikai bűvészmutatványt igazolnak az elkövetkező évek.

Azt jól tudjuk, hogy a CV-események kockázata a vérnyomás nagyságával növekszik, az eddig vizsgált legkedvezőbb alsó tartomány az SBP tekintetében pedig 110-115 Hgmm (3). A 140/90 Hgmm-es határérték azonban kompromisszum eredménye volt, mert arról van bizonyítékunk, hogy efelett több a CV-esemény, mint ez alatt. Az ACCORD és a HOPE-3 alátámasztotta, hogy a túlzott vérnyomáscsökkentés nem biztosít további védelmet $(7,9)$. A SPRINT-tanulmányban viszont a végpontok akkor is javultak, ha a szisztolés vérnyomás 121,4 Hgmm-ig csökkent (8). A SPRINT-tanulmány vérnyomásmérési technikája eltért a másik kettőtől, ezért az eredményei vitathatók. A célvérnyomás 2003 óta hullámvasúton ül, hol alacsonyabb, hol pedig magasabb, mint 140/90 Hgmm. Egy biztos, a vérnyomást pontosan kell megmérni, mert ez a kulcsa minden más tennivalónak, hiszen a hipertóniás betegeket mindenképpen kezelni kell: életmód-változtatással és gyógyszerrel (két vagy éppen három komponensü fix dózisú kombinációval); mert ez csökkenti a CV-morbiditást és -mortalitást. De kérem, valaki mondja meg, mennyi is a hipertónia?

\section{Irodalom}

1. Crim MT, Yoon SS, Ortiz E, et al. National surveillance definitions for hypertension prevalence and control among adults. Circ Cardiovasc Qual Outcomes 2012; 5: 343-351. doi: 10.1161/CIRCOUTCOMES.111.963439.

2. Whelton PK, Carey RM, Aronow WS, et al. C/AHA/AAPA/ABC/ ACPM/AGS/APhA/ASH/ASPC/NMA/PCNA Guideline for the Prevention, Detection, Evaluation, and Management of High Blood Pressure in Adults: A Report of the American College of Cardiology/ 
American Heart Association Task Force on Clinical Practice Guidelines. J Am Coll Cardiol 2017 Nov 7. pii: S0735-1097(17)41519-1. doi: 10.1016/j.jacc.2017.11.006.

3. Lewington S, Clarke R, Qizilbash N, Peto R, Collins R; Prospective Studies Collaboration. Age-specific relevance of usual blood pressure to vascular mortality: a meta-analysis of individual data for one million adults in 61 prospective studies. Lancet 2002; 360 1903-1913. Erratum in: Lancet 2003; 361: 1060.

4. Kannel WB, Gordon T, Schwartz MJ. Systolic versus diastolic blood pressure and risk of coronary heart disease. The Framingham study. Am J Cardiol 1971; 27: 335-346.

5. Chobanian AV, Bakris GL, Black HR, et al. National Heart, Lung and Blood Institute Joint National Committee on Prevention, Detection, Evaluation, and Treatment of High Blood Pressure; National High Blood Pressure Education Program Coordinating Committee. The Seventh Report of the Joint National Committee on Prevention, Detection, Evaluation, and Treatment of High Blood Pressure: the JNC 7 report. JAMA 2003; 289: 2560-2572. Erratum in: JAMA 2003; 290: 197.

6. Mancia G, Fagard R, Narkiewicz K, et al. Task Force Members. 2013 ESH/ESC Guidelines for the management of arterial hypertension: the Task Force for the management of arterial hypertension of the European Society of Hypertension (ESH) and of the European Society of Cardiology (ESC). J Hypertens 2013 Jul; 31(7): 1281-357. doi: 10.1097/01.hjh.0000431740.32696.cc.

7. ACCORD Study Group, Cushman WC, Evans GW, Byington RP, Goff DC Jr, et al. Effects of intensive blood-pressure control in type 2 diabetes mellitus. N Engl J Med 2010; 362: 1575-1585. doi: 10.1056/NEJMoa1001286.

8. SPRINT Research Group, Wright JT Jr, Williamson JD, Whelton PK, et al. A Randomized Trial of Intensive versus Standard Blood-Pressure Control. N Engl J Med 2015; 373: 2103-2116. doi: 10.1056/NEJMoa1511939.

9. Lonn EM, Bosch J, López-Jaramillo P, et al. HOPE-3 Investigators. Blood-Pressure Lowering in Intermediate-Risk Persons without Cardiovascular Disease. N Engl J Med 2016; 374: 2009-2020. doi: 10.1056/NEJMoa1600175.

10. Böhm M, Schumacher H, Teo KK, et al. Achieved blood pressure and cardiovascular outcomes in high-risk patients: results from $\mathrm{ON}$ TARGET and TRANSCEND trials. Lancet 2017; 389: 2226-2237. doi: 10.1016/S0140-6736(17)30754-7.

11. Huang $Y$, Su L, Cai X, et al. Association of all-cause and cardiovascular mortality with prehypertension: a meta-analysis. Am Heart J 2014 Feb; 167(2): 160-168.e1. doi: 10.1016/j.ahj.2013.10.023.

A közlemény megjelenését az Egis Gyógyszergyár Zrt. támogatta. A közleményben szereplő adatok és információk a szerző nézeteit tükrözik. Bármely említett termék alkalmazásakor az érvényes alkalmazási előírás az irányadó.

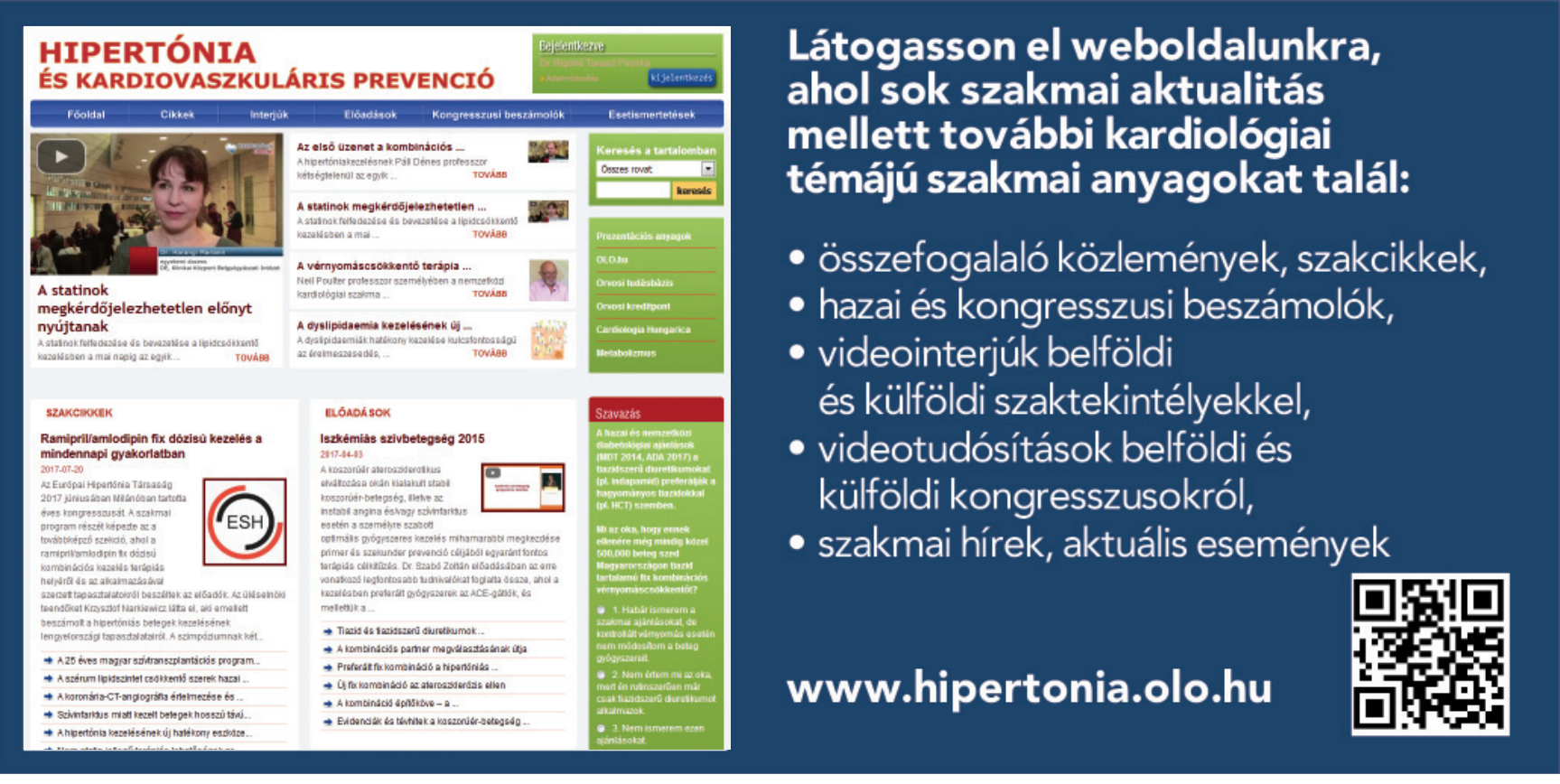

